\title{
Enhancement of Water Cooled Internal Combustion Engines Using Peltier Effect
}

\author{
Abdelrhman Abdalla Elian \\ Mechanical Power Department \\ NSPO \\ Aswan, Egypt \\ abdelrhman3lian90@gmail.com \\ O. M. Dahab \\ Mechanical Power Department \\ Faculty of Engineering \\ Aswan, Egypt \\ omardahab55@gmail.com
}

\author{
W. A. Aissa \\ Mechanical Power Department \\ Faculty of Energy Engineering \\ Aswan, Egypt \\ waessa@energy.aswu.edu.eg \\ Mohamed Fathy Cidek \\ Mechanical Power Department \\ Faculty of Energy Engineering \\ Aswan, Egypt \\ mfsadik@yahoo.com
}

\begin{abstract}
This paper investigate the influence of using the Peltier module in enhancing the water cooled internal combustion engine. The result of demonstrating model will be compared with the current vehicle (Sahin 1996, single overhead cam 1400 cm3) specification. Thermo Electric Cooler (TEC) or Peltier module converts the electric energy to heat energy. The performance of thermoelectric devices is still a challenge, and many approaches have been researched to overcome such obstacle. The result of modelling system temperature difference is from $40 \%$ to $50 \%$ established cooling system temperature difference on former vehicle.
\end{abstract}

Keywords - Internal combustion engine radiator ,Thermoelectric module, Peltier module, Radiator cooling enhancement.

\section{INTRODUCTION}

Even with the superb research efforts and contributions on the enhancement efficiency of internal combustion engine is astonishing. Researchers don't reach their target on that research $.100 \%$ efficiency engine is considered a science fiction ,For engines, high efficiency is not only high performance . But also , decrease the consumption of fuel, decrease the emission , optimize vehicles' designs by reducing their weight . Cooling systems on internal combustion engines are at the top of list enhancing systems. There is a necessity for a new innovation heat transfer manners to improve heat dissipation inside engines . the main technique of any modification is that modification of the actuators of any system . Actuator of any system considered the muscles of it. Actuators of cooling system on the internal combustion heat engine that may be enhanced are (pump ,diameter of galleries, thermostat, radiator shape or size and its fan , etc. ) .

For pump modification :

Abdul Latiff et al. [1] made a simulator test rig for vehicle's engine (Proton Wira [4G 15] ) . They compared the performance of engine with common coolant driven pump and small electrical coolant pump ; They concluded that small electrical coolant pump was more effective than the engine driven one

Wang et. 1. [2] stated the difference between mechanical and electrical water pump of internal combustion engine .They found that the electrical water pump had the better performance than the mechanical one.

For modification of thermostat :

Chastain , J. [3] made six experiments in internal combustion engine (4.6L V8 engine) with temperature tracking and power consumption, seeking on fully controlled by electronic control module (ECM) for the radiator fan, thermostat valve, and coolant pump to enhance temperature tracking ability and reduce the parasitic energy losses.

For Radiator modification :

Khripach et al. [4] designed a mockup modified thermoelectric cooling radiator for internal combustion engine .Further, the determining the parameters as(electric power, thermal one ,temperature of cooling fluid ,etc. ) .Moreover, finding that the required power was $815.4 \mathrm{~W}$,temperature difference about 13 , aerodynamic resistance $2.3748 \mathrm{KPa}$ with error factor $5 \%$.

For pump vs. power consumption analytically :

Li et al. [5] present an exergy-based analysis for optimizing the design of an automotive cooling system depending on 2nd law of thermodynamic basis . Moreover, Studying the recommended water flow rates to various speeds to get the minimum consumed power by the water pump. At each speed there exists an optimal water flow rate that corresponds to the minimum consumed power and is close to a minimum in exergy destroyed.

Analytically and numerically modification :

Luptowski et al. [6] enhanced the vehicle cooling system simulator to Enhanced Vehicle Engine Cooling System Simulation (E-VECSS) which predicted the effect of cooling system performance on power consumption and reduction on warm-up time. Further this active cooling simulation was applied to a Detroit Diesel series 60engine .

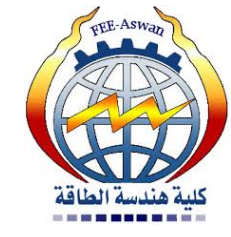


Production power modification:

AISSA and Mohamed , I. , K. [7] tested two different thermoelectric materials, loads and car speeds at both cases of insulating and non-insulating of the exhaust pipe. Results indicated that the produced voltage is directly proportion to car speed and load. Further, they concluded that the greater Seebeck co-efficient, the greater produced voltage. Moreover, they stated that the insulation of the exhaust pipe remarkably enhances the produced voltage.

KIM, S. et al. [8] fabricated auxiliary heat exchanger with 72 TEG modules ,results were maximum output power almost $75 \mathrm{~W}$, the module efficiency $=2.1 \%$. Overall efficiency of electric power to heat power $=0.3 \%$ at car speed $80 \mathrm{Km} / \mathrm{H} r$.

\section{SCOPE AND OBJECTIVE}

- Study current Internal combustion engine 's cooling system .

- Explore thermoelectricity phenomena

- If the co-operation of TEC with cooling system effective or not knowing that The consumed electric power for radiator fan is about $300 \mathrm{Watt}$.

- The main purpose of this paper is to reduce the consumed electric power by radiator fan by changing its dimension and power supply keeping its heating dissipation properties .

\section{THERMOELECTRICITY}

\section{A. Seebeck Effect}

Thomas Johann Seebeck in 1821 haply discovered that there is a generating volt from a metal bar when the ends of this bar exposed to temperature gradient .

Temperature gradient causes the flux movement of electrons from the hot partition to the cold one. This means voltage generation

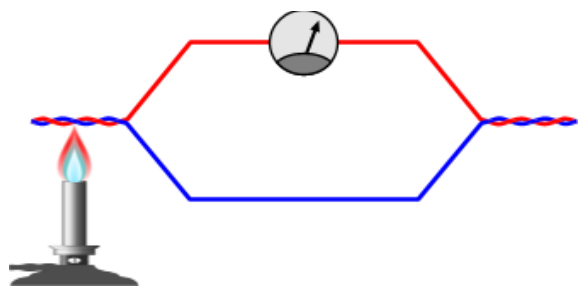

Figure (1) Seebeck effect diagram [9]

$$
\begin{aligned}
& \mathrm{V}=\alpha(\text { Th-Tc }) \\
& \mathrm{V}=\text { VOLTS in V }
\end{aligned}
$$

$\alpha=$ SEEBECK co-efficient in couples $\mathrm{V} / \mathrm{K}$

$\mathrm{Th} \& \mathrm{Tc}=$ high and low temperatures respectively in $\mathrm{K}$.

\section{B. Peltier Effect}

Jean Charles Peltier in 1834 observed that after applying current on two junctions dissimilar metals thermal energy emits and absorb in each junction .

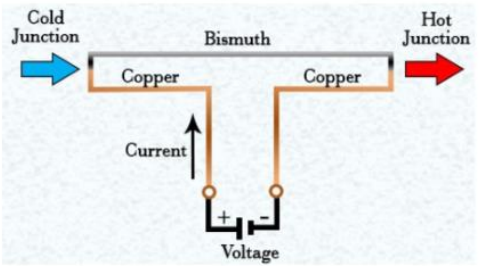

Figure (2) Peltier effect diagram [9]

$$
\dot{\mathrm{Q}}=\left(\pi_{\mathrm{A}}-\pi_{\mathrm{B}}\right) \mathrm{I}
$$

$\pi_{A} \& \pi_{B}=$ Peltier co-efficient for the dissimilar metals in volt $\mathrm{I}=$ the electric current form A to B in Ampere

$\dot{Q}=$ the generated heat in Watt

\section{IV-TEC CHARACTERISTICS CURVES :}

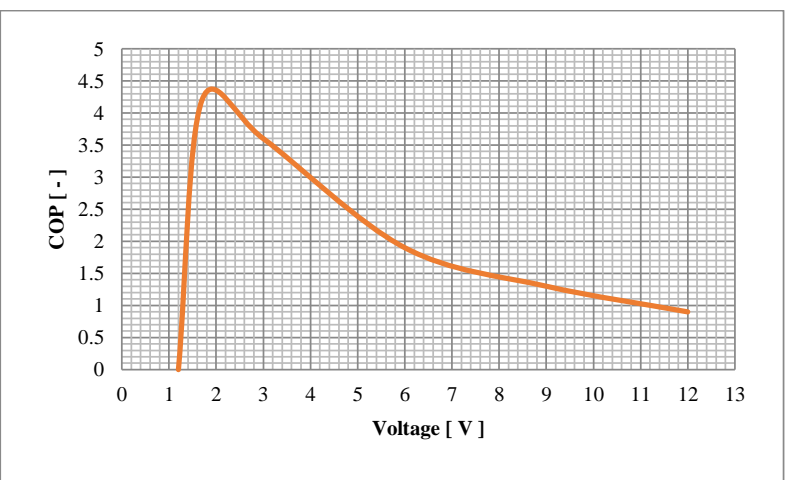

Fig. (3) Applied Voltage versus COP [10]

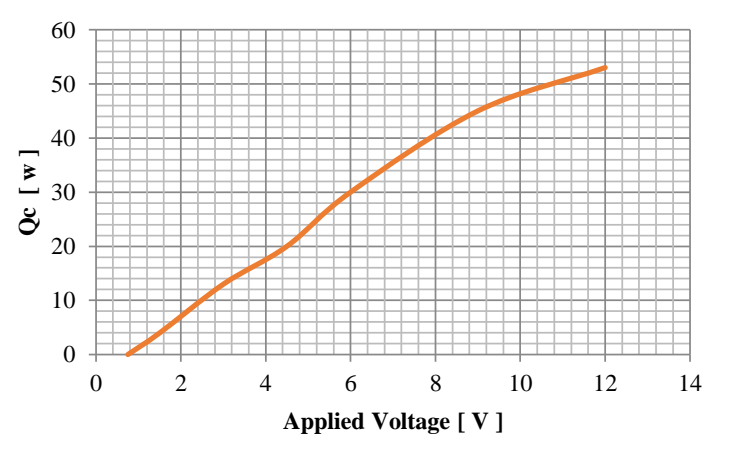

Fig (4) Applied Voltage Versus Heat dissipation [10]

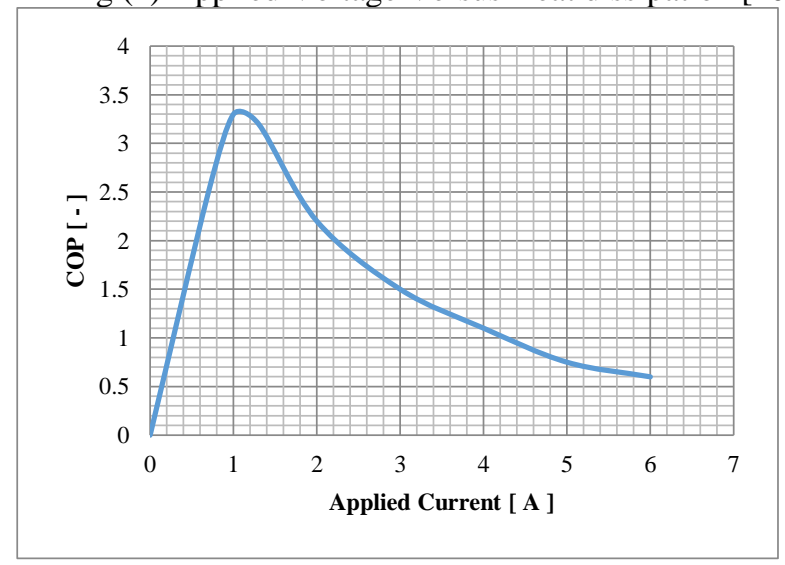

Fig (5) Applied current Versus COP [10] 


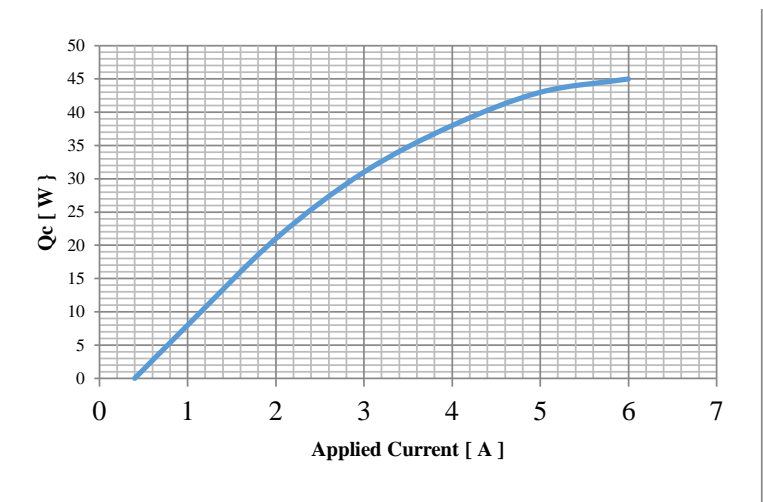

Fig (6) Applied current versus Heat dissipation [11]

\section{V-INTERNAL COMBUSTION ENGINE \\ A-COOLING SYSTEM}

Cooling process plays an important role on internal combustion engine performance a great amount of heat energy generated while generating power from engine due to the generated heat from combustion chamber. In case of the absence of cooling system this will be an inevitable disaster since the engine block will melt, lubricant will seizure from pistons ,so piston will melt inside cylinder liner.

\section{B- COMPONENTS COOLING SYSTEM}

\section{1-Coolant pump or water pump}

2-Coolant as water with ethylene glycol

3-Water jacket around pistons

4-Water gallery

5-Coolant temperature sensor

6-Thermostat

7-Radiator

8-Fan of Radiator

9-Expansion tank

\section{VI-METHODOLOGY}

1. Prepare two reservoirs : one as heat source(as heat engine ) and the other is as heat $\operatorname{sink}$ (as radiator).

2. Pump hot water from first reservoir to the other reservoir .

3. Passing through TECs with their heat sinks and copper housing .

4. By comparing temperatures of first and last reservoirs .

5. Those steps to study the influence of adding TECs to cooling system on internal combustion engine model.

VII-BLOCK DIGRAM FOR MODEL SYSTEM

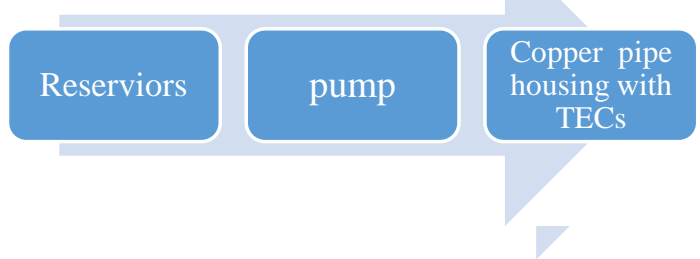

Fig. (6) block diagram for modeling installation

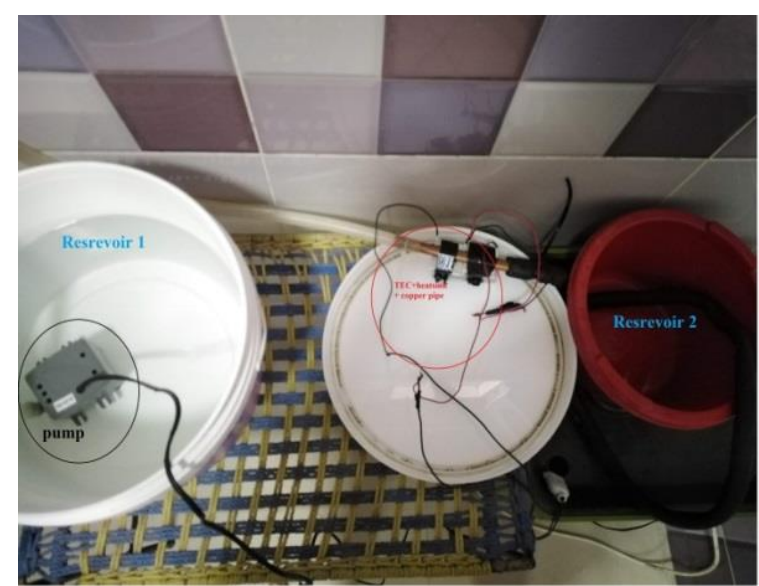

Fig. (7) real modelling constructions

VIII- SYSTEM COMPONENTS

A-Pump :

Table (1) model pump specification .

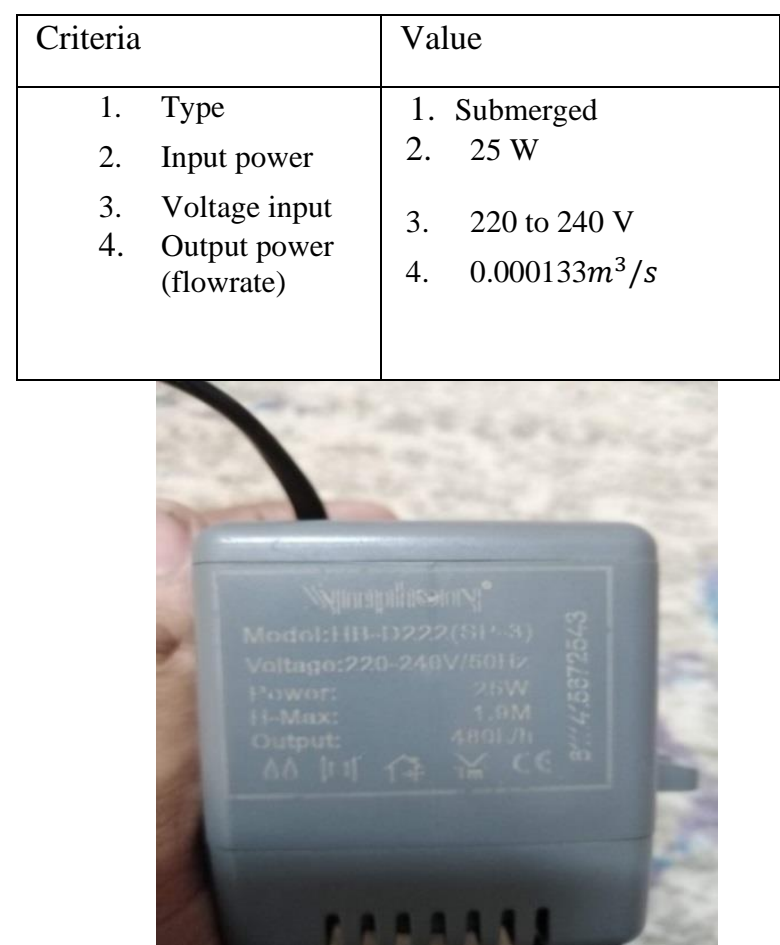

Fig. (8-a) the submerged pump used for the test

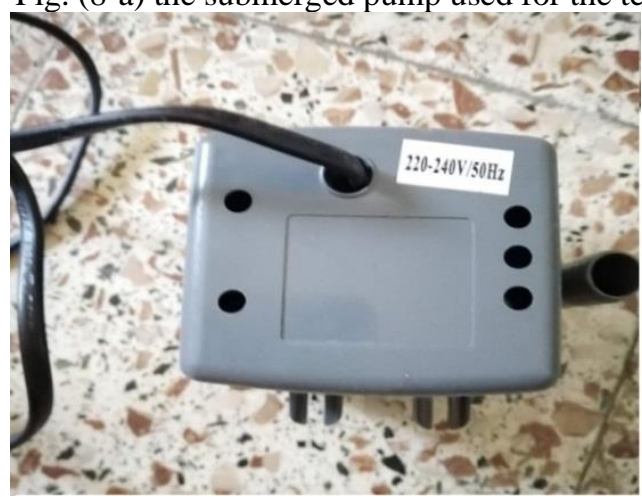

Fig (8-b) The model submerged pump for the test 
B- Thermoelectric modules specification

The two modules are connected in series

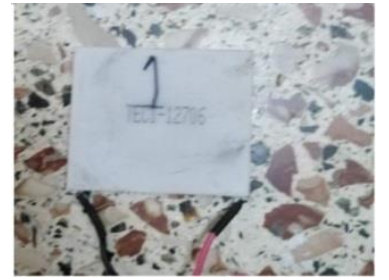

Fig.(9) TEC module no. 1

Table (2) TEC specifications

\begin{tabular}{|c|c|}
\hline Criteria & Value \\
\hline - $\quad$ Type & - $\quad$ TEC 1 - 12706 \\
\hline - $\quad$ Applied current & - $\quad 1.5 \mathrm{~A}$ \\
\hline - $\quad$ Applied voltage & - $\quad 4.5 \mathrm{~V}$ \\
\hline - $\quad$ No. of modules & - 2 TECs \\
\hline - $\quad$ Required power & - $\quad 13.5 \mathrm{~W}$ \\
\hline - $\quad$ TEC cold bare surface & - $\quad-100 \mathrm{C}$ \\
\hline - $\quad$ TEC hot bare surface & - $\quad 680 \mathrm{C}$ \\
\hline - No. of attached heatsinks & - 2 heatsinks \\
\hline
\end{tabular}

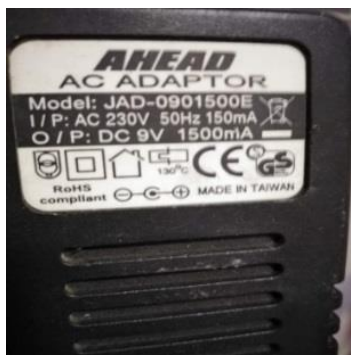

Fig.(10) The power supply used for TECs IX-MEASURING INSTRUMENTS

a) Multi-meter

That device which measure the many (Direct voltage, Alternate voltage, direct current, alternate current, resistance , capacitance, etc. ) .

This type of device is digital one .

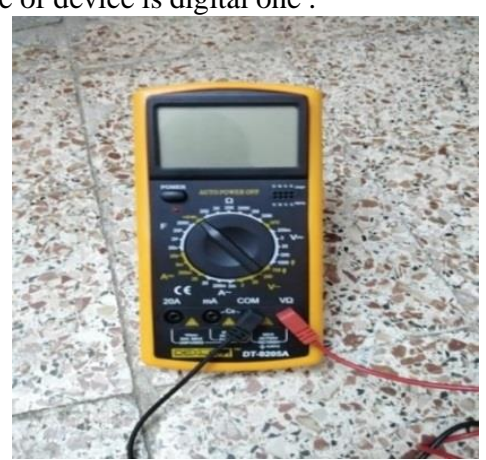

Fig. (11) Digital Multimeter

b) Infrared thermometer :

Not contact thermometer which used instead of five thermocouples at $\mathrm{s}$ (Water entrance, top surface of TEC hot, bottom surface of TEC cold and Water outlet ) .

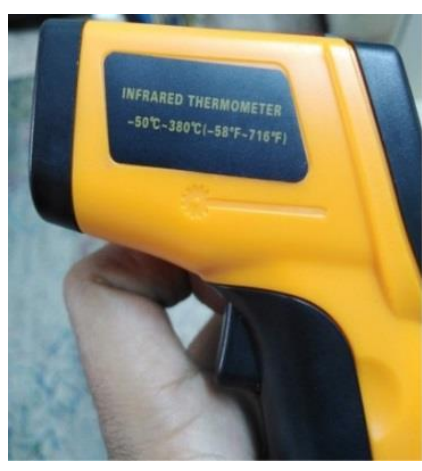

Fig. (12-a) Infrared thermometer

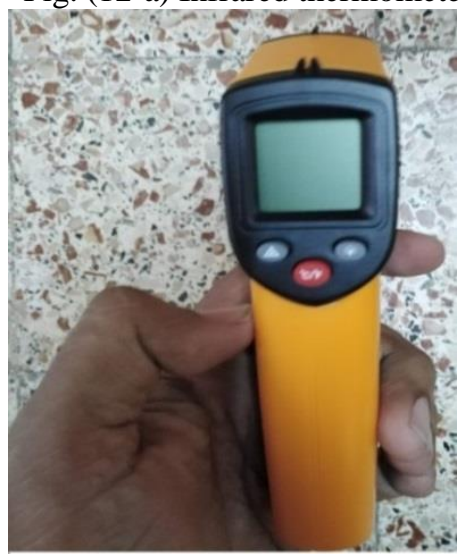

Fig. (12-b) Infrared thermometer control panel and its monitor

$\mathrm{X}$-DISCUSION

After applied power sources for (TECs and Pump )

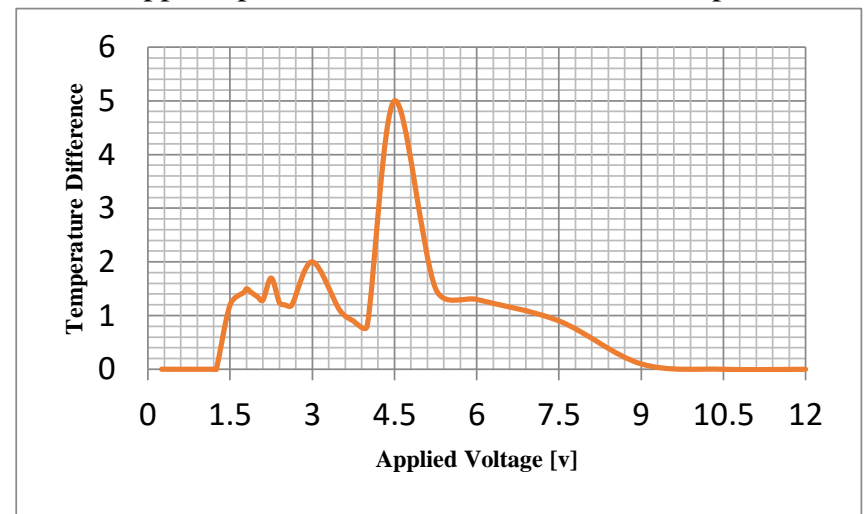

Fig. (13) Applied Voltage versus Temperature difference . 


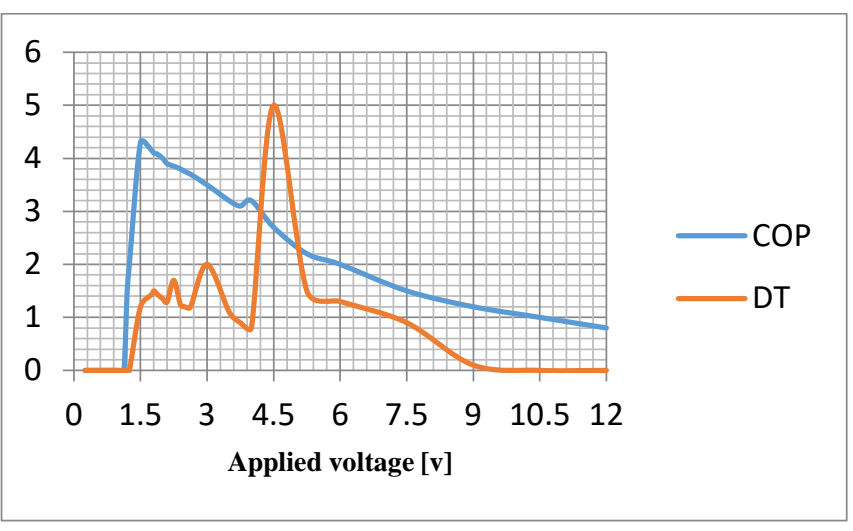

Fig. (14) Applied Voltage versus Temperature difference and Coefficient of performance .

From pervious charts : maximum temperature difference at 4.5 volts. The power supply used in the system was 9 voltages and 1.5 amperes as shown in fig.(10). The power supply was suitable for two TEC devices .

Water at first tank with temperature $=48{ }^{\circ} \mathrm{C}$

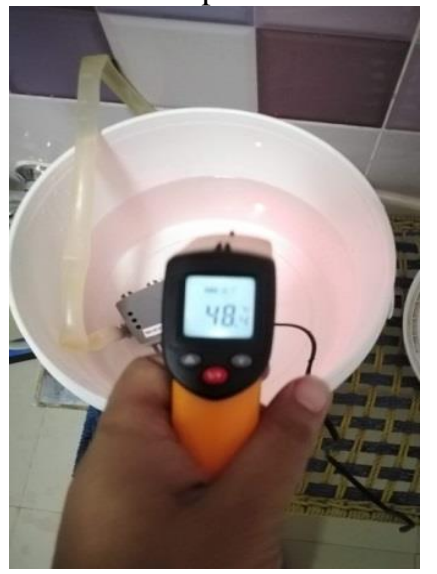

Fig. (13) Water at first reservoir before passing through the system After passing through the constructed system Water exit this system at $=43{ }^{\circ} \mathrm{C}$.

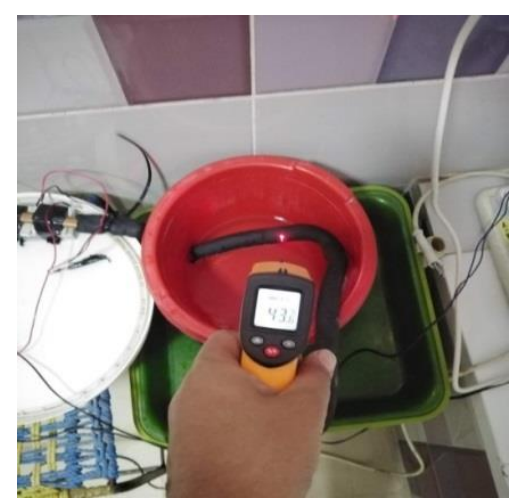

Fig. (14)Water temperature after passing the system

The temperature difference of the system is equal to half of the temperature difference of the internal combustion engine cooling system (prototype system ) .

\section{XI-CONCLUSION}

The temperature difference of the system is equal to half of the temperature difference of the internal combustion engine cooling system (prototype system ) .
I recommend making this enhanced system on vehicles with respect to number of TECs and power consumption. (Taking power consumption into consideration ) .

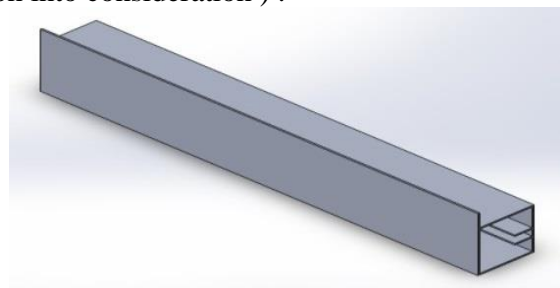

Fig. (15) recommended mockup aluminum housing.

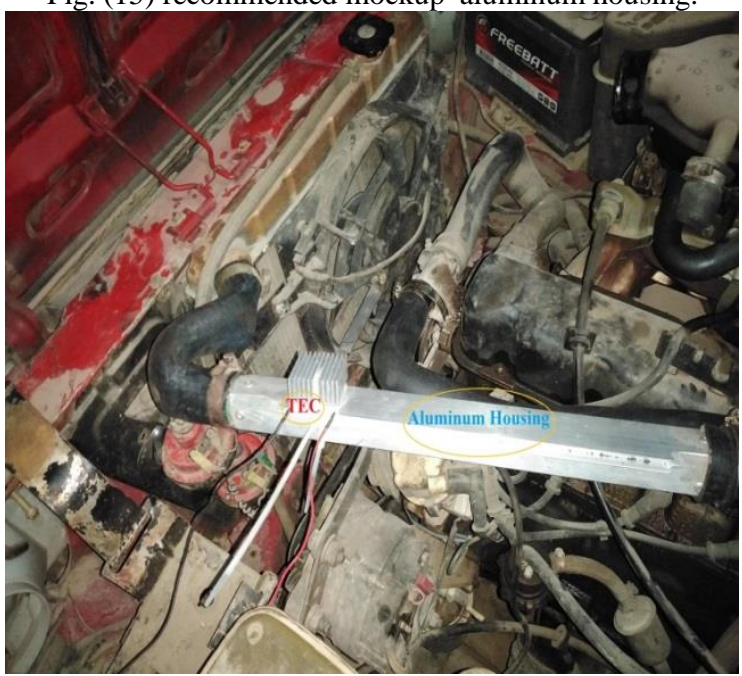

Fig.(16) Actual Aluminum housing with TEC installed on vehicle .

\section{XII-REFERENCES}

1. M. L. M. TANSUNi, Z. ABdUl LATIFF, H. NASUTION,M. R. M. PERANG ,H. M. JAMIL AND M. N. MisSERI "PERFORMANCE OF A WATER PUMP IN AN AUTOMOTIVE ENGINE COOLING SYSTEM " JuRnal TEKNOLOGI , AUtOMOTIVE DEVELOPMENT CENTRE (ADC), FACUlTy OF MeChANICAL ENGINEERING, INSTITUTE FOR VEHICLE SYSTEMS (IVESE) UNIVERSITI TEKNOLOGI MALAYSIA ,2016.

2. X. WANG , X. LIANG , Z. HAO AND R. CHEN “COMPARISON OF ELECTRICAL AND MECHANICAL WATER PUMP PERFORMANCE IN INTERNAL COMBUSTION ENGINE " INTERNATIONAL JOURNAL OF Vehicle Systems Modelling AND Testing, 10 (3), PP. 205-223.

3. JOHN CHASTAIN " INTERNAL COMBUSTION ENGINE COOLING STRATEGIES: THEORY AND TEST " MASTER THESIS, 2006, CLEMSON UNIVERSITY .

4. N. A. KHRIPACH, V. S. KOROTKOV AND I. A. PAPKIN " THERMOELECTRIC COOLING RADIATOR FOR INTERNAL COMBUSTION ENGINE " INTERNATIONAL JOURNAL OF MECHANICAL ENGINEERING AND TECHNOLOGY (IJMET) VOLUME 8, ISSUE 11, NOVEMBER 2017 PP. 668-675

5. Li, H., and Figliola, R., "Optimization of an Automotive COOLING SYSTEM BASED ON

EXERGY ANALYSIS”, SAE PAPER NO. 2004-01-3541, 2004.

6. LUPTOWSKI, B., ARICI, O., JOHNSON, J., AND PARKER, G., "DEVELOPMENT OF THE ENHANCED

VeHICLE AND ENGINE COOLING SySTEM SimULATION AND APPLICATION TO ACTIVE

COOLING CONTROL”, SAE PAPER NO. 2005-01-0697, 2005. 
7. W. A. AISSA AND I. K. MOHAMED " RECOVER OF WASTE HEAT FROM AN OLD AUTOMOTIVE ENGINE EXHAUST " INTERNATIONAL JOURNAL OF MECHANICAL AND PRODUCTION ENGINEERING, ISSN: 2320-2092, VOLUME- 5, ISSUE-7, JUL.2017 .

8. S. KIM, S. PARK S. KIM AND S. H. RHI " A THERMOELECTRIC GENERATOR USING ENGINE COOLANT FOR LIGHT-DUTY INTERNAL COMBUSTION ENGINE-POWERED VEHICLES " JOURNAL OF ELECTRONIC MATERIALS, VOL. 40, No. 5, 2011 .

9. HTTPS://WWW.PINTEREST.COM/PIN/546694842251420662/

10. SPECIFICATION OF THERMOELECTRIC MODULE TEC1-12706 "TEC1-12706-ENGLISH.PDF".

11. ROßMANN ELECTRONICGMBH PRODUCT SPECIFICATION OF THERMOELECTRIC COOLING MODULE ' TECB1.PDF'

12. المو اصفات الفنية و الصيانة للسيارة شاهين

13. HTTP://HYPERPHYSICS.PHYASTR.GSU.EDU/HBASE/TABLES/THRC N.HTML .

14. TONYE. K. JACK AND MOHAMMED M. OJAPAH"WATERCOOLED PETROL ENGINES: A REVIEW OF CONSIDERATIONS IN COOLING SYSTEMS CALCULATIONS

WITH VARIABLE COOLANT DENSITY AND SPECIFIC

HEAT", INTERNATIONAL JOURNAL OF ADVANCES IN

ENGINEERING \& TECHNOLOGY, MAY 2013. ISSN: 2231-1963 . 